\title{
An Inventory of Tibetan Sound Laws
}

\section{NATHAN W. HILL}

\section{Introduction}

Scholars of Indo-European historical linguistics have long found it convenient to refer to well known sound changes by the name of the researcher who first noticed the correspondences the sound change accounts for. Because of the proven utility of such named sound laws in Indo-European linguistics, the explicit listing and naming of sound laws in the TibetoBurman family could be expected to bring similar benefits. ${ }^{1}$

Here I present those sound changes which are widely accepted to have occurred between the Tibeto-Burman Ursprache and Old Tibetan. I name each law after the first researcher known to me to have described it. The first four proposals, those of Shafer, von Koerber, Walleser, and de Jong, concentrate more on the interpretation of the Tibetan script than actual sound changes from prc-Tibctan to Tibetan, and thus are labelled 'rules' rather than 'laws'. The sound laws have been ordered such that later laws can employ the results of earlier ones as evidence.

\section{Shafer's rule, the sub-phonemic status of aspiration}

The Tibetan script distinguishes the unaspirated consonant series $k, c, t, p$, ts from the aspirated consonant series $k h, c h, t h, p h, t s h$. The distribution between voiceless aspirated and voiceless unaspirated stops in Written Tibetan is nearly complementary. Only as a simple Anlaut are the two series distinctive. Robert Shafer appears to be the first to have put forth the conjecture that aspiration in Tibetan was originally non-distinctive ( $1950 / 5 \mathrm{I}$ : pp. 722-723). He did not however give an explanation of counter examples.

\footnotetext{
${ }^{1}$ This essay uses the Library of Congress system for transliterating Tibetan with the exception that the letter $q$ is transliterated as ' $h$ ' rather than with an apostrophe. The Library of Congress system is used for Burmese also, with the exception that : and 'are transliterated as $h$ and $?$ rather than " and ${ }^{\prime}$. For Chinese I provide the character followed by Baxter's Middle Chinese (I992), an OC reconstruction compatible with the current version of Baxter and Sagart's system, and the character number in Karlgren (I964). Like in Baxter's own recent work, for Middle Chinese I use 'ae' and ' $e a$ ' in place of his original ' $x$ ' and ' $\varepsilon$ '. I do not however following him is changing ' $i$ ' to ' $t$ '. The current version of Baxier and Sagart's Old Chinese system has not yet been published. In general it is similar to the system presented in Sagart (I999), with the changes that type b syllables are unmarked and type a syllables are marked (following Norman 1994) with phargynealised consonants. The current version also posits final $-r$ for 泚馨 Xiesheng series which mix final $-n$ and $-j$, and uvulars for 谐警Xiesheng series that mix velar and glottal initials (cf. Sagart and Baxter 2009). All languages apart from Tibetan, Burmese, and Chinese are cited after the source in which the cited forms appear. I would like to thank Bill Baxter, Wolfgang Behr, John Bentley, Guillaume Jacques, Mark Miyake, and Laurent Sagart for various kinds of help.
} 
If one takes into account the phonological word and not just the syllable the distinctiveness of aspiration in Anlaut position can itself be considerably reduced. By far the majority of occurrences of unaspirated voiceless initials in Old Tibetan are word internal, either derivational suffixes or the second element of a compound. Aspiration occurs word initially, and can be seen as a non-phonemic super-segmental attribute of the phonological word (Hill 2007). Even so, there are a small number of exceptions to these generalisations, in particular ci 'what' and kun 'all'. Such cases require further study.

\section{Walleser's rule, the difference between $<$ gy $>$ and $<$ g.y $>$}

The Old Tibetan orthographic distinction of $\langle\mathrm{gy}\rangle$ and $\langle\mathrm{g} . \mathrm{y}\rangle$ represents the phonetic distinction of [gi] and [g]]. It is necessary to analyze the letter $\langle y\rangle$ into two phonemes: the glide / $y /$ when it is written as a min-gź $i$ w and a phonemic feature of palatalisation /i/ when written as a ya-btags $\approx$. This analysis was first proposed by Max Walleser (I926: p. 9). Other strategies are available to distinguish $<$ gy $\rangle$ from $\langle$ g. $y\rangle$, but in addition to the arguments in favour of Walleser's view presented in Hill ('forthcoming'), this rule facilitates the elegant description of other sound changes, in particular Li's second Law. ${ }^{2}$

\section{3 von Koerber's rule, phonemic status of the palatals}

Noticing that that the character $<y>$ standing for the phonemic feature of palatalisation / i/ cannot follow a dental or a palatal ${ }^{*}<\mathrm{dy}>,{ }^{*}<\mathrm{cy}>$, but can follow velars and labials $<\mathrm{ky}>$, $<$ by $>$, the palatals may be analyzed as palatalized dentals, i.e. /ti / for $<c>$, /ni/ for $<\tilde{n}>$, $/$ di/ for $\langle\mathrm{j}\rangle, / \mathrm{si} /$ for $\langle\dot{s}\rangle$, and /zi/ for $<\dot{z}\rangle$. The fact that Indic alphabets have a palatal series probably inclined the originators of the Tibetan script to choose to spell these sounds as single consonants rather than as <ty $>$ and $<$ dy $>$ (von Koerber 1935: pp. I2I, §69).

Von Koerber describes the identification of the palatals as palatalised dentals as a synchronic fact (1935: pp. 120-12I). He has been followed in this by numerous scholars (e.g. Miller I956: p. 348 note 2, Kjellin 1975). Gong and Beyer however accept the palatals as phonemes but propose that they originate as a merger of the palatalised dentals and palatalised dental affricates (Gong [1977]2002: p. 388, Beyer I992: pp. 8I-84). Velar and labial stops can be followed by both an orthographic $\langle r\rangle$ and an orthographic $\langle y\rangle$. Dentals are followed by $<r>$ only. The palatals and affricates are followed by neither $\langle\mathrm{r}\rangle$ or $<y>$. The inability of the dental affricates to directly precede $\langle\mathrm{r}\rangle$ would appear to weaken the supposition that palatalised dental affricates are one origin of the palatals. Analyzing the palatals as palatalised dental stops restores the dental stops to the distribution of the labials and velars, but analyzing the palatals as palatalised dental affricates still leaves the dental affricates with a distribution deficient with respect to the other consonants. I therefore reject Gong and Beyer's speculation that one origin of the palatals is as palatalised dental affricates. As for Gong and Beyer's suggestion that the palatalised dentals are the origin of the palatals, there is no need to propose this as a historical change rather than a synchronic analysis.

\footnotetext{
${ }^{2}$ Gong (1977[2002]) presents a divergent interpretation and a useful summary of previous research.
} 


\section{4 de Jong's rule, spelling conventions before laterals and rhotics}

Old Tibetan phonemically distinguishes both voiced and voiceless laterals and voiced and voiceless rhotics. The voiceless lateral $/ 1 /$ as a simple initial is spelled as $<\mathrm{lh}\rangle$, the voiceless rhotic $/ \mathrm{r} /$ as $<\mathrm{hr}>$. The prefix $/ \mathrm{g}-/$ is written as $<\mathrm{k}->$ before voiceless laterals and rhotics. The prefix /s- / may be written as $<\mathrm{z}\rangle$ before a voiced lateral, as seen in the pairs 10 'a report' zlo 'report, say' and $\log$ 'turn around', zlog 'turn something around' (Hahn 1999). In other cases no distinction in spelling is made between the voiced and voiceless lateral. The spelling <sl $>$ can like <zl $>$ represent /sl/ as in the pairs of verbs lan, lanis 'rise' and slon, bslanis, bslan, slons 'raise', ldob, lobs 'learn' and slob, bslabs, bslab, slobs 'teach' (Li I933: pp. I39-I40), but <sl> can also represent /sl/ as in the following denominative verb and noun pairs: slad, bslad 'mix, adulterate' : thad 'an alloy'; slan 'to mend' : lhan-pa 'a patch'; sle 'to braid' : The 'a braid' ( $\mathrm{Li}$ I933: pp.I39-I40). The spelling <bl> can thus represent /bl/ or $/ \mathrm{bl} /$. The clearest examples of $<\mathrm{bl}>$ reflecting $/ \mathrm{bl} /$ are the past stem of the verbal root $\sqrt{l}$ lag 'read', spelled (present) klog, (past) blags, (future) klag, (imperative) lhogs with the phonemic interpretations /glog/, /blags/, /glag/, and /logs/ (de Jong 1973), and the past stem of the verbal root $\sqrt{l}$ lub 'bedeck' spelled klub, blubs, -, - with the phonemic interpretations /glub/, /blubs/, -, - (Eimer 1987). In some Dunhuang manuscripts the past stem of $\sqrt{\text { lag }}$ 'read' is even spelled $<$ plags $>$, <phlags $>$, and $<$ plhags $>$ (de Jong 1973). Many examples could be pointed to where $\langle\mathrm{bl}>$ reflects $/ \mathrm{bl} /$; one such example is $\sqrt{\text { lan }}$ 'take' with the stems len, blanis, blan, lonis, whose orthographic and phonemic interpretations coincide.

Although $\mathrm{Li}$ can be credited with the realisation that the spellings $<\mathrm{l}>$ and $<\mathrm{lh}>$ are a pair in the same way as $\langle\mathrm{b}\rangle$ and $\langle\mathrm{p}\rangle$, but not in the way of $\langle\mathrm{p}\rangle$ and $<\mathrm{ph}\rangle$ (Li I933: pp. I39-I40), the extention of this realisation to clusters can be credited to Pulleyblank.

Pulleyblank has pointed out, in correspondence, that the orthographic distinction $l h$ - versus $l$ might be used to account for $k l$ - versus $g l$-, the former being interpreted as " $g l h$-. The absence of an initial ${ }^{*} p l$ - to match $b l$ - (and of ${ }^{*} r h$-, possibly, to match $r l$-), tells against this interpretation;

(Sprigg 1972: p. 552 note I0).

De Jong came to the same realisation independently of Pulleyblank, and demonstrated with philological evidence that there is an initial $p l$ - to match $b l$ - The works of Eimer (1987) and Hahn (1999) depend on de Jong and are unaware of the earlier contributions of $\mathrm{Li}$ and Pulleyblank. Although dubbing this rule 'Li's rule' or 'Pulleyblank's rule' is perhaps justified, I find it most appropriately named 'de Jong's rule.'

\section{Sa-skya Pandita's Law, *g- $>$ d- before graves, ${ }^{*} \mathrm{~d}->\mathrm{g}$ - before acutes}

As a synchronic fact $\mathrm{d}$ - and $\mathrm{g}$ - are in complementary distribution as the initial of a cluster with an obstruent in Old Tibetan. Before grave consonants (labials and velars) $d-$ appears, and before acute consonants (dentals and palatals) g-appears. This synchronic fact is however not a rule for the phonemic analysis of Old Tibetan like the proceeding four, but has historical significance. Jacques (200I) demonstrates with comparative evidence that originally separate ${ }^{*} \mathrm{~d}$ - and * $\mathrm{g}$ - have fallen together. Before the consonant $-\mathrm{r}$ - they remain distinct even in 'Tibetan. Although Jacques' 200 I presentation remains unpublished, he presents some of the relevant comparative data in Jacques (2008: pp. 53-54). These data show that a morphological 
* $\mathrm{g}$ - prefix in animal names can be distinguished from a morphological prefix ${ }^{*} \mathrm{~d}$ - in body parts.

A comparison with Rgyalronic cognates demonstrates that the animal prefix was originally velar (or even uvular) and not dental.

\begin{tabular}{llll}
\hline Japhug Rgyalron & Zbu Rgyalron & Tibetan & Meaning \\
\hline qa-ljab & re-liê $\chi$ & glag & eagle \\
qa-zo & b-ie? & g.yan & sheep \\
qro & qhrô $\chi$ & grog-mo & ant \\
\hline
\end{tabular}

Since $\mathrm{dr}$ - is just as possible as gr- in Old Tibetan, the velar nature of this prefix is also confirmed by Tibetan grog-ma 'ant' (instead of *drog-ma).

In the case of the body part prefix $\mathrm{d}$ - Jacques does not present direct Tibetan cognates in the Rgyalronic languages, but the Japhug Rgyalron words tu-mtshi 'liver' and turmke 'neck' demonstrate that in Tibetan words such as gdon 'face', $d b u$ 'head' and $d p u \dot{n}$ 'back' there is a morphological prefix, and it was originally a dental Jacques 2008: 57).

The intellectual history of this law is difficult to trace. The realisation that the complementary distribution of $\mathrm{d}$ - and g- before obstruents implies a set of sound changes from pre-Tibetan to Tibetan appears to originate only with Jacques (200I). $\mathrm{Li}$ acknowledges the fact that $\mathrm{d}$ - and g- are in complementary distribution, when he writes that their "notorious compensatory behaviour has made many people suspect them of a single origin" (1933: p. I36). Although a number of earlier scholars do correctly describe the distribution of d- and g- (Schmidt 1839: p. I8; Schiefner 1852: p. 328; Foucaux 1858: pp. I06-IO7), I have been unable to find a scholar earlier than $\mathrm{Li}$ who makes explicit their complementary distribution. This may well be linked with the fact that the importance of complementary distribution as a linguistic idea only reached prominence around or after the time of Li's writing.

The correct description of $\mathrm{d}-$ and $\mathrm{g}$ - has its origins in the Tibetan grammatical tradition, and is discussed in the sūtras attributed to Thonmi Sambhota. Dbus-po blogsal (thirteenth century) is the author of the earliest known commentary on these texts (cf. Mimaki I990, I992), which suggests that far from being eighth-century texts, they only became available in the twelfth or thirteenth century. Sa-skya Pandita Kundgah Rgyal-mtshan (II82-I2SI) appears to have written the earliest known statement of these distributions, in an account that acknowledges no awareness of Thonmi Sambhota (Miller 1993: p. 137). The most appropriate name for this law is then 'Sa-skya Pandita's Law.'

\section{Houghton's Law, * ${ }^{*} \mathbf{i}>\tilde{\mathbf{n}}$}

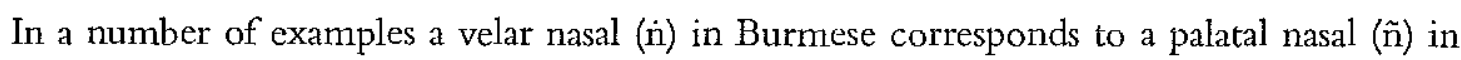
Tibetan. Combined with the observation that the velar nasal is never palatalised in Tibetan ${ }^{*}<\dot{n} y>/ \dot{n} \dot{n} /$, these correspondences suggest a sound change pre-Tibetan * ${ }_{n} i>$ Old Tibetan กิ. 


\begin{tabular}{lll}
\hline Burmese & Tỉbetan & Meaning \\
\hline nian & gñan & pestilence \\
ñhāḥ & $\begin{array}{l}\text { brña } \\
\text { ñăh }\end{array}$ & borrow \\
ña & fish \\
\hline
\end{tabular}

Houghton suggested the first two of these examples (I898: 52), and the third was added by Benedict (I939: p. 228 note 26). Benedict was the first to make explicit that such a correspondences suggests a reconstruction */ni $/$. However, since Houghton brought forth the comparisons that lead naturally to such a suggestion, and because I would prefer to reserve the moniker 'Benedict's Law' for the change li $>$ ź, I have chosen to dub this sound change in honour of Houghton.

If Chinese comparisons are added to those with Burmese the chart provided above can be augmented as follows.

\begin{tabular}{|c|c|c|c|c|}
\hline Meaning & Tibetan & Pre-Tibetan & Burmese & Chinese \\
\hline pestilence & gñan & ${ }^{*}$ gniian & ñan & \\
\hline & ña & ${ }^{*}$ nina & n்äḥ & 焦 ngjo < * na (0079a) \\
\hline borrow & brña & *brnia & ṅhāḥ̣ & \\
\hline gums & rñil/sñil & ${ }^{*} / \mathrm{rnnilil} /{ }^{*}$ sniilil & & 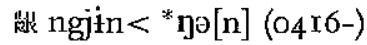 \\
\hline
\end{tabular}

\section{Benedict's Law, *li $>\mathbf{z}$}

Benedict does not specifically discuss this sound change, but proposes it by way of comparing Burmese liy 'four' with Tibetan bzi 'four', which he reconstructs *bli (1939: p. 215).

\begin{tabular}{lllll}
\hline Meaning & Tibetan & Pre-Tibetan & Burmese & Chinese \\
\hline four & bźi & ${ }^{*}$ blii & liy & m $\mathrm{sijH}<<^{*}$ s.li[j]-s (os I 8a) \\
field & źin & ${ }^{*}$ liị & lay & II den $<{ }^{*}$ liij (o362a) \\
ground & gźi & ${ }^{*}$ glii & mliy & \\
\hline
\end{tabular}

The two examples 'four' and 'field' appear to be the only well agreed on examples. Schuessler suggests the comparison 'ground' (2007: p. 299). Jacques draws attention to Japhug Rgyalron tr-lu 'milk' which suggests Tibetan źo ${ }^{*}$ lio 'yoghurt' (2008: p.I28). One might also consider comparisons among Tibetan gź 'bow', Burmese liy 'bow' and Old Chinese 矢 syijX $<{ }^{*} l_{o}$ ij? (os60a) 'arrow' but the Tibetan vowel is wrong. There are also grounds internal to Tibetan for such a reconstruction (Gong [1977] 2002: pp. 39I-392).

\begin{tabular}{ll}
\hline $\mathbf{1}-$ & $\mathbf{z}-$ \\
\hline $\begin{array}{l}\text { logs 'side' } \\
\text { lan' 'rise' }\end{array}$ & $\begin{array}{l}\text { gźogs 'side of the body' }<\text { 'gliogs } \\
\text { bzen 'rise' < }\end{array}$ \\
\hline
\end{tabular}

\section{Chang's Law, assimilation of $b$ - before nasals}

Betty Chang (I97I: p. 738) discovered that cluster initial $b$-assimilates to the labial nasal $m$ before nasals. 
*bn $>$ mn, e.g. $\sqrt{ }$ nan 'suppress', past $*$ bnans $>$ mnand

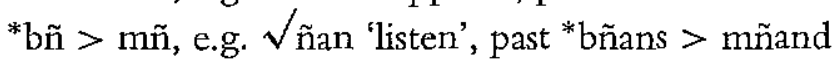

The seemingly anomalous $m$ - in the past stem becomes thereby a subcase of the nearly ubiquitous $b$ - prefix of the past stem.

\section{Coblin's Law, loss of prefixes}

Prefixes are lost when the resulting cluster is not phonotactically possible (Coblin I976). This law greatly facilitates the internal reconstruction of the Tibetan verbal system.

*hrk > rk, e.g. V rkam 'long for', present *hrkam > rkam

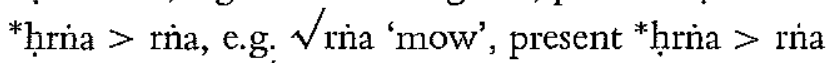

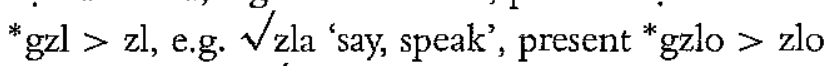

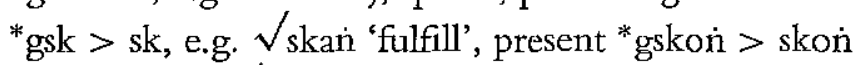

*bb $>$ b, e.g. $\sqrt{ }$ bya 'do', past *bbyas $>$ byas

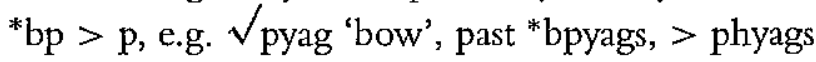

In each such case the positing of a lost prefix resolves some anomaly in a verb's paradigm, and renders the verb in question an example of a paradigm type which is otherwise well attested. Here is not the place to discuss these proposals in detail. ${ }^{3}$ One example may however prove illustrative. Some verbs have an 'o' vowel in their present stem, but not in the past or future; one such verb is skori, bskaris, bskan, skoris 'fulfill'. Of those verbs which have such an 'o' in the present, those where a $g$ - prefix in the present stem is phonotactically possible have such a prefix, e.g. gsod, bsad, gsad, sod 'kill'. Reconstructing the present stem of skon to *gskon < 'gskain not only accounts for the presence of the 'o' vowel in both skon and gsod, but also for the lack of a $g$ - in the former and its presence in the latter.

\section{ro Li Fang-Kuei's first Law, epenthesis after $\mathbf{h}$}

When an $h$ precedes a fricative, lateral, of $r$, a dental stop is inserted between $h$ and the following consonant (Li I933: p. I49).

*hs $>$ hits, e.g. $\sqrt{ }$ so 'nourish', present *hso $>$ ḥtsho

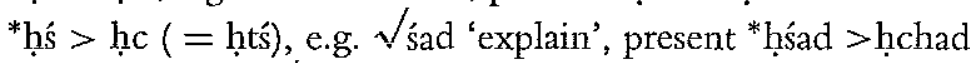

${ }^{*}$ h $z>$ ḥdz, e.g. $\sqrt{ }$ zug 'plant', present *hzugd $>$ ḥdzugs

*hź > hjj (= háź), e.g. źo 'milk', present *hźo > hjo

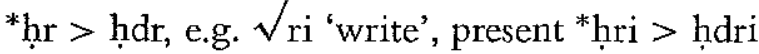

The effect of this sound change is more complicated before laterals. Simon proposes the change *dl- $>$ ld based on groups of related words such as ldum-po and zlum-po 'round', ldog-pa, log-pa 'reverse (intrans.)' and zlog-pa 'reverse (trans.), ldon-pa and lon-ba 'be blind', ldan-ba, lanis 'rise' and slan-ba 'raise' (Simon I929: p. I87). ${ }^{4}$ The results of Li's first Law is

\footnotetext{
${ }^{3}$ For a complete discussion of Tibetan verb morphology see Hill (IoIO: pp. xv-xxi).

${ }^{4}$ Simon proposes other rules of metathesis such as ${ }^{*} \mathrm{kl}>\mathrm{lk},{ }^{*} \mathrm{kr}>\mathrm{rk}$ but these remain speculative.
} 
followed by this metathesis proposed by Simon, and then the cluster is simplified following Coblin's Law.

$$
\begin{aligned}
& \text { *hal }>\text { *ḥdl > *hld >ld, e.g } \sqrt{\text { lad }} \text { 'chew', present *hlad }>\text { *hdlad }>\text { ldad }
\end{aligned}
$$

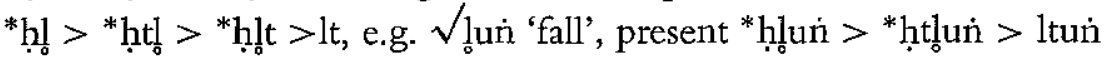

\section{Li Fang-Kuei's second Law: *ry- > rgy-.}

Li Fang-Kuei proposes the change *ry $>$ rgi in order to make Tibetan <brgyah $>$ /brgiah/ 'hundred' and <brgyad $>$ /brgiad/ 'eight' more closely parallel Old Chinese 百 paek $<{ }^{*}$ p 'rak

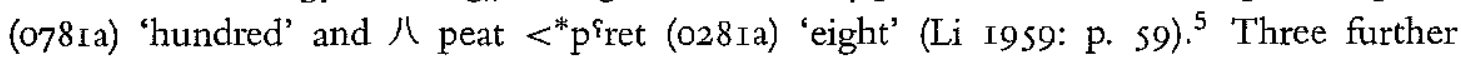
examples of this correspondence are available. With no mention of an earlier authority Schuessler proposes the comparison of Tibetan rgyu <* ryu 'flow' with Old Chinese 流 ljuw ${ }^{*}$ [r]u (I IO4,a) (2003: p. 238, 2007: p. 362) and Tibetan rgyud <* ryud 'continuum' with 繂率 Iwit $<{ }^{*}[\mathrm{r}]$ ut (498a) 'rope' (2003: p. 238). ${ }^{6}$ Pulleyblank in a different context proposes a second relevant pair of words (I962: p. 2I 5): Old Tibetan brgyal < *bryal 'sink down, faint' and ho-brgyal 'fatigue, weariness' and Old Chinese 罷痕 bje $<{ }^{*}[\mathrm{~b}]$ raj 'fatigue'. Schuessler (2007: p. SI2) however doubts the validity of this comparison. ${ }^{7}$

\begin{tabular}{|c|c|}
\hline Old Tibetan & Old Chinese \\
\hline brgyah 'hundred' & i paek $<{ }^{*}$ prak “hundred' (o78Ia) \\
\hline brgyad 'eight' & 八 peat $<{ }^{*} \mathrm{p}^{\mathrm{s} \text { ret }}$ 'eight' (028Ia) \\
\hline rgyu 'flow' & 流 ljuw $<^{*}[\mathrm{r}] \mathrm{u}$ 'fllow' (I I O4a) \\
\hline rgyud 'continuum' & 彎率 Iwit < *[r]ut 'rope' (498a) \\
\hline brgyal 'sink down, faint' & 簬波 bje $<^{*}[\mathrm{~b}] \mathrm{raj}$ 'fatigue' (0026a, 0025d) \\
\hline
\end{tabular}

Since $\mathrm{Li}$ did not recognise the difference between $/ \mathrm{y} /$ and $/ \mathrm{i} / \mathrm{his}$ reconstruction can be understood as either $* /$ ry/ or $* / \mathrm{ri} /$ in Pre-Tibetan. Old Burmese ry-corresponds to both Old Tibetan rgy- (Old Burmese ryä 'hundred' and Old Tibetan brgya 'hundred') and Old Tibetan ź- (Old Burmese ryak 'day', Old Tibetan źag 'day'). It is probably judicious to reconstruct Old Tibetan ź < pre-Tibetan *ri and Old Tibetan rgy $<$ pre-Tibetan ${ }^{*}$ ry, because a change * ri $>z$ is parallel to Benedict's Law *li $>z$ z.

\footnotetext{
${ }^{5}$ The mismatch in voicing of the Tibetan voiced initials and the Chinese voiceless initials in these words has not been accounted for.

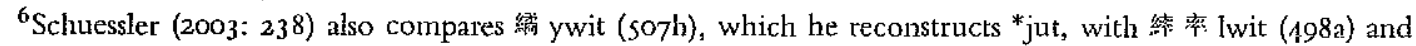
with Tibetan rgyud 'string, rope' (more like 'continuum, lineage'). In the Baxter-Sagart system there is no Old Chinese initial $j^{-}$; Middle Chinese y- generally originates from 1 - or uvulars (cf. Sagart and Baxter 2009).

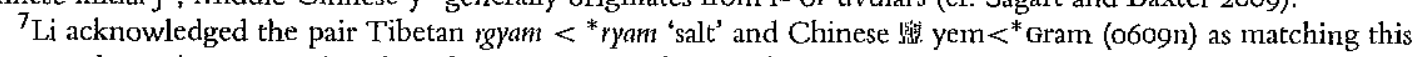
correspondence (I976: p. 46). Schuessler reconstructs 盟 yem< $<^{*}$ rjam (2003: p. 238, 2007: p. 554), which certainly matches the Tibetan better, but he does not comment on the reconstruction $y<{ }^{*} r$. In the Baxter-Sagart system this comparison is no longer compelling. Simon had earlier suggested this same comparison (I929: pp. I88, \$39, \#253) and an additional example rgyan 'distance' 溒 hjwonX $\left.<{ }^{*}[\mathrm{G}] \mathrm{wa}_{\mathrm{a}} \mid \mathrm{n}\right]$ ? (O256f) 'distance', which no longer appears to fit this correspondence.
} 


\begin{tabular}{ll}
\hline Old Burmese & Old Tibetan \\
\hline ry- & rgy- \\
ryã 'hundred' & brgya 'hundred' \\
rhac<*'rhyat 'eight' (Nishi I999: 47). & brgyad 'eight' \\
ry- & ź- \\
ryak 'day'8 & źag 'day' \\
ryap 'to stand, stop' & źabs 'foot' \\
l- & ź- \\
liy 'four' & bźi 'four' \\
lay 'field' & źin 'field' \\
\hline
\end{tabular}

Three instances of the change ${ }^{*}$ ry $>$ rgy require no comparison to other Tibeto-Burman languages. The place name Uddiyana in Tibetan becomes U-rgyan or O-rgyan. Middle Indic languages regularly loose a final $-\mathrm{a}$; this yields *Uḍdiyan. If $\underset{\mathrm{d}}{\mathrm{d}}$ were pronounced as a rhotic, or heard as one by Tibetan ears this gives *Uriyan, and such a pronunciation was nativised following this sound change to U-rgyan (cf. Jacques and Chen 2010: p. 7 I note 7). Also, in the Dunhuang document PT 1047 there is vacillation between ryags and rgyags as the spelling of a word for divination board. This vacillation probably indicates a process of nativising a non-Tibetan word ryags. Similarly, the name of the Źanźun emperor found in the Dunhuang documents PT I047 and PT I287 as Lig myi rya or Lig myi rhya in the later Rgyal rabs bon kyi hbyun gnas appears as Lig mi rgya (Uray 1968: pp. 293-294). Finally, Tauscher mentions that in the Gondhla Proto-Kanjur there is regular confusion between the spellings rya and rgya (2008: p. xxxvi).

\section{Simon's Law, ${ }^{*} \mathrm{mr}>$ ḥbr}

Simon proposed the sound change pre-Tibetan * $m r>$ Tibetan $h b r$ (I929: pp. I87, I97 §86). Five of the examples Simon presented can no longer be accepted:

I) Simon compares bro 'dance' with 舞 mjuX $<$ *m(r)a? (oIO3g) 'dance'. The absence of an initial $h$ in the Tibetan and lack of a vowel correspondence suggests that this comparison is false.

2) Simon compares Tibetan brod 'taste' with Chinese 䛶 mjijH $<$ *m[ə][t]-s (os3 Ig) 'taste'. The lack of an initial $h$ in the Tibetan and a medial -r- in the Chinese invalidates this comparison.

3) Simon compares Tibetan sbrul 'snake' with 䦎 min 'an ethnonym' on the mistaken belief that the later means 'snake' (Schuessler 2007: p. 386).

4) Simon compares Tibetan hbum 'Ioo,00o' with Old Chinese 萬 *mjonH < *mans (0267a) 'ro,000'; both Tibetan and Chinese lack medial -r-.

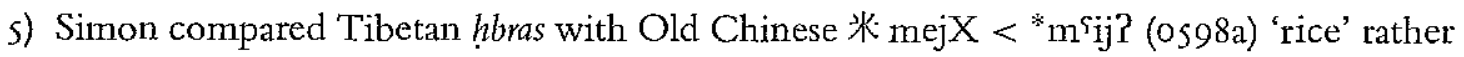
than 橡 ljejH $<{ }^{*}$ mə-ríat $(0340 g)$.

Gong (I995, \#368) compares 妊婎 nyimH <*n[ə]m-s (0667i,k) 'pregnant' with sbrum 'pregnant' which he reconstructs *smrum. No 瑎聲 xiesheng contacts suggest an $\mathrm{m}$ - in the

\footnotetext{
${ }^{8}$ In the r999 version of Sagart's reconstruction Chinese 往 yae $\mathrm{H}<{ }^{* b}$ Nlaks (080oj) 'night' might have been taken to suggest an original lateral initial in this word (Sagart I999: p. I60), however the current reconstruction, [G](r)ak-s, if still considered a cognate, favours a rhotic.
} 
series GSR 667. Gong appears to be following the suggestion of Pulleyblank (I979: p. 36) that based on the transcription 任 那 for Mimana (a fifth century polity, which was a member of the Kaya 加耶 federation on the Korean peninsula) that this 諧聲 xiesheng series once had initial *m-. The evidence for reading 任 那 as Mimana comes from the日本書糺 Nihonshoki, where in the record of 垂任 Suinin it is also spelled 彌摩那 (Kojima et al. 1994: p. 295). Sagart argues that 妊妊 nyimH $<* n[ə]$ m-s 'pregnant' (0667i,k) is etymologically derived from 任 nyim < *n[ə]m (0667f) 'to carry'. The semantics are thus not favourable to Gong's suggestion. Sagart also proposes an etymological connection with 南 nom $<{ }^{*} n^{\mathrm{S}}[$ [ə]m (0650a) 'south', which argues against the $\mathrm{m}$ - initial proposed by Pulleyblank (Sagart I988). Jacques (2003: p. 124) citing Pan (2000: pp. 240-24I) instead compares Tibetan sbrum 'pregnant' with 辛 yingH $<{ }^{*}\left[[\mathrm{i}] \mathrm{n}-\mathrm{s}\left({ }^{*} \mathrm{~m}\right.\right.$.rəm-s is also a possible reconstruction).

The following table presents the evidence in favour of Simon's proposal known to me.

\begin{tabular}{|c|c|c|c|}
\hline Tibetan & Meaning & Chinese & Meaning \\
\hline ḩbras & rice & 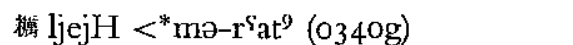 & rice \\
\hline ḥbrog & nomad & 牧 mjuwk < ${ }^{*}$ mruk (IO37a) & herdsman \\
\hline habri-mo & female yak & 解 maew $<{ }^{*} \mathrm{mr}^{\mathrm{i}} \mathrm{u}^{\mathrm{IO}}(0979 \mathrm{j})$ & \\
\hline ḥbreñ & braid & 维 zying $<^{*}$ m.lon (o892b) & rope, cord \\
\hline sbrań & fly, bee & 門 ying <*m.rəy (o892a) & \\
\hline sbrul & snake & 抽 $\mathrm{xjwijX}<^{*}[\mathrm{mo}] \mathrm{ujp}^{11}$ (os72a) & snake \\
\hline sbrum & pregnant & 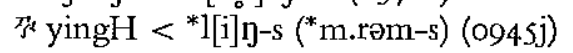 & pregnant \\
\hline
\end{tabular}

I find the evidence of this sound change compelling but not yet convincing. Before such a correspondence can be wholeheartedly embraced the Tibetan words containing the cluster smr-, such as smra 'say', nur-smrig 'saffron', smre 'suffering', smreg 'root, remainder', smran, smren '(ritually) say' must be explained.

I have previously argued that $h$ - represented a voiced velar fricative in Old Tibetan and not a nasal (Hill 2005: pp. I26-I27, 2009a: pp. I27-I3I). If the sound change ${ }^{*} m r->h b r-$ were valid this would suggest that $h b r$ - had the pronunciation $[\mathrm{mbr}]$, known from Common Tibetan, already in the earliest Old Tibetan. The arguments presented in Hill (2005: pp. I26-I27) against interpreting a pre-consonantal $h$ as a homorganic nasal are therefore also arguments against the sound change ${ }^{*} m r->h b r$.

Coblin on the basis of the comparison of Old Tibetan rmain 'horse' and Old Burmese mran 'horse' contrastingly suggests a change *nr>rm (1974). Because the Ursprache of these languages almost certainly pre-dates the domestication of the horse, I believe that this correspondence is likely characteristic of Wanderwörter.

\footnotetext{
${ }^{9}$ Confer Sagart (2003: p. I29).

${ }^{10}$ The 廣頡 Guanyun also has the readings $\mathrm{li}<{ }^{*}$ mə-ro and $\operatorname{loj}<{ }^{*}$ mo-r ${ }^{S_{0}}$.

${ }^{11}$ Baxter and Sagart now reconstruct ${ }^{*}[\mathrm{r}] \mathrm{u}[\mathrm{j}]$ ? with the irregular sound change ${ }^{*}{ }_{\mathrm{r}-}>\mathrm{x}-$. I prefer to follow their earlier reconstruction. The medial $-\mathrm{r}-\mathrm{can}$ be confirmed with a comparison with Old Burmese mruy 'snake'.
} 


\section{I3 Sun's Law, fortition of laterals}

Sun (I993: p. 334 note 20I) appears to be the first scholar to explicitly propose the sound change *ml- $>$ md. ${ }^{12}$ He connects this change to Li's first Law before laterals *hl $>$ ld without elaboration. The following two tables present the relevant data known to me.

\section{Internal Tibetan Evidence}

\begin{tabular}{|c|c|c|}
\hline d- & ld- and bź- & 1 \\
\hline $\begin{array}{l}\text { mdons-pa 'blind' } \\
\text { mdan-pa 'cheek' } \\
\text { hdug 'stay' } \\
\text { ḥdod 'desire' }\end{array}$ & $\begin{array}{l}\text { ldon-pa 'go blind'<*hlon-pa (Li's I }{ }^{\text {st }} \text { Law) } \\
\text { ldan-pa 'cheek'<*hlan-pa (Li's It Law) } \\
\text { bźugs 'stay'<*bliugs (Benedict's Law) } \\
\text { bźed 'desire'<"blied (Benedict's Law) }\end{array}$ & $\begin{array}{l}\text { lon 'be blind' } \\
\text { lugs 'way, manner' }\end{array}$ \\
\hline
\end{tabular}

Gong instead proposes that the explanation for the $-d$ - versus $-\dot{z}-$ in these last two examples is a palatalisation used morphologically to form honorifics ( 1977 [2002]: p. 390). His proposal would yield the reconstructions bzugs 'stay' <*bdings and bzed 'desire' < bdined. ${ }^{14}$ One may suppose that Gong would reject the comparison of bźugs 'stay' with lugs 'way'.

\section{Comparative Evidence}

\begin{tabular}{|c|c|c|c|}
\hline Tibetan & Pre-Tibetan & Burmese & Chinese \\
\hline mdah 'arrow' & *mlah & mlāḥ 'arrow' & $\begin{array}{l}\text { 射 zyek }<\text { *m-lAk } \sim \text { mo-lAk } \\
\text { (o807a) 'hit with bow and arrow' }\end{array}$ \\
\hline ḥdom-pa 'fathom' & & lam 'fathom' & 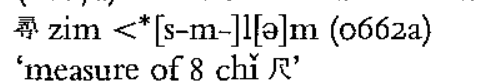 \\
\hline
\end{tabular}

A parallel change *ml $>$ mth could be suggested. The only possible instance known to me is mthil <*mlil 'bottom 'floor' which Gong ( $1980, \# 79$; I995, \#169) compares to Old Burmese mliy 'earth, ground'. However, Schuessler instead compares Burmese mliy with Tibetan gź $i$ 'ground' (2007: p. 299). Since the change *li $>z$ is well established and the semantics are more similar, this comparison is superior.

The fact that there is evidence for an original 1- both in the cluster md-and in the cluster hd indicates that the single change ${ }^{*} \mathrm{ml}>\mathrm{md}$, is not explanatorily sufficient. However, one cannot propose the sound change * $h l>$ hd because * $h 1$ is already used as the input of Li's first Law ${ }^{*} \mathrm{hl}>\mathrm{ld}$. How to reconstruct cases of hd- where there is evidence for an original $1-$ is a problem requiring further attention.

\footnotetext{
${ }^{12}$ When this article was in production, I discovered Bodman had made this suggestion before Sun, I980. It would thus be better to refer to it as Bodman's Law.

${ }^{13}$ The difference in vocalism requires explanation.

${ }^{14}$ Compare Simon's earlier proposal that *gdi >gź (r929: p. I9I et passim).
} 


\section{I4 Laufer's Law, ${ }^{*}{ }_{a},{ }^{*} w_{\ni}>0$}

Laufer noted that where Burmese has -wa Tibetan often has -o (I898/I899: part III, p. 224; 1976: p. 120). The first two examples are Laufer's, the next four from Sagart (2006: p. 2I I), and the last from Benedict (1972: p. 106).

\begin{tabular}{lll}
\hline Burmese & Tibetan & meaning \\
\hline thwan & thoi & plough \\
thwā & mtho & span \\
swāh $^{\text {Is }}$ & hgro & go \\
wanh & sgor-mo & round \\
wa & gro-ma & potentilla anserina \\
awa & go & space \\
swäh & so & tooth \\
\hline
\end{tabular}

Noting that all Old Tibetan words which have the diphthong - $w a-$ are open syllables (grwa 'corner,' bcwa 'ten,' phywa 'a class of gods,' rtswa 'grass,' hwa 'fox,' zwa 'hat,' rwa 'horn') and the pair ho-dom 'fox tail pendant' and hwa 'fox', I previously suggested that Laufer's Law did not apply to open syllables (Hill 2006: pp. 88-90). It is clear from the above examples that some Tibetan words with open syllables are valid examples of this correspondence and my explanation must be caste aside. Guillaume Jacques suggests that instances of -wa in Tibetan open syllables should be reconstructed as *uba in pre-Tibetan (2009). I accept this explanation.

The previous research treating this correspondence (Laufer 1898/I899, Gong 2002[I980], Matisoff 2003, Hill 2006, Jacques 2009) appears unaware that Inlaut Written Burmese -waoriginates from -0 - in early Old Burmese (cf. Ba Shin 1962: pp. 27-28 and pp. 38-39, Maung Wun 1975: p. 89, Nishida 1972: pp. 258, Dempsey 2001: pp. 222-225). Because the correspondence of Written Burmese Inalut -wa- (Old Burmese -o-) with Tibetan -o- is a retention in Tibetan, the rubric 'Laufer's Law' should not be applied to such instances and instead be reserved for those cases where Burmese Anlaut wa- corresponds to Old Tibetan -o-. Laurent Sagart points out that in such cases the Tibetan cognate begins with $g_{-}$(2006: p. $2 \mathrm{II}) \cdot{ }^{17}$

\footnotetext{
${ }^{15}$ Gong (1980: \#172; 1995: \#38, 3 I0) and Lüce (I985: chart $x$, \#20́) give knva 'go proceed', which apparently a better match. Judson ( 1893 ) does not have this word in this meaning.

${ }^{16}$ Sagart cites this as 'gor', probably deriving this form from gor-mo 'round' in Jäschke (I $88 \mathrm{I}$ ). However, Jäschke cites clearly his source as the extremely unreliable Schroeter ( 1826 ). This work was compiled by F. Francesco Orazio della Penna (I680-I745) as a Tibetan-Italian glossary. Schroeter died while revising the work and learning Tibetan; the editors who saw the work through publication knew no Tibetan (cf. Simon I964; Bray 2008).

${ }^{17}$ Matisoff does not like these comparisons (2007: pp. 437-438) but Sagart still does (2008: p.I 54).
} 


\begin{tabular}{llll}
\hline Tibetan & meaning & Burmese & meaning \\
\hline go & space & awa & space \\
gro-ma & potentilla anserina & wa & tuber \\
sgor-mo round $^{18}$ & wanh & round \\
\hline
\end{tabular}

Gong further notes that Tibetan -o- often corresponds to Old Chinese lavio-velars (and presumably labio-uvulars if he recognised them). He reconstructs *wa and *wo as sources of Tibetan o (2002[1980]: p. 24).

\begin{tabular}{|c|c|c|c|}
\hline Chinese & meaning & Tibetan & meaning \\
\hline 㨨 kjwak< < Caqwak (o778b) & seize & ḥgog & take away forcibly \\
\hline F hju<* Gw(r)a (0o97a) & go & hgro & go \\
\hline 苛 hjuH < ${ }^{*}[\mathrm{G}]^{w}(\mathrm{r})$ as $(0097 \mathrm{o})$ & taro & gro-ma & tuber \\
\hline 羽 hjuX $<^{*}[\mathrm{G}] \mathrm{w}(\mathrm{r}) \mathrm{aP}(0098 \mathrm{a})$ & feather & sgro & feather \\
\hline 为 ngjweH< ${ }^{*} \eta^{\text {wajs }}(0027 \mathrm{k})$ & false, cheat & rnod & deceive \\
\hline 排 hwaeH< $<^{*}[\mathrm{G}]$ whras (0044-) & birch bark & gro-ga & birch bark \\
\hline H hjwijH $<{ }^{*}[\mathrm{G}]{ }^{w}$ we $[\mathrm{t}] \mathrm{s}\left(0 \cos ^{2} 3 \mathrm{a}\right)$ & stomach & grod & stomach \\
\hline 友 hjuwX $<{ }^{*}[\mathrm{G}]{ }^{w_{0}}$ ? (o995e) & friend & grogs & friend \\
\hline 運 hjwij< $\left.<^{*}[\mathrm{G}]{ }^{\mathrm{w}} \partial \mathrm{j}\right](\mathrm{OS7Id})$ & go against & hgol & part, deviate \\
\hline 蹅 $\mathrm{kjwij}<{ }^{*}[\mathrm{k}]^{\text {waj }}$ (os7oa) & return (v.) & hakhor & circle \\
\hline
\end{tabular}

Because Burmese wa 'tuber' (compared to Chinese 苂*[G]w(r)as and Tibetan gro-ma) has Anlaut $w a$ - and the Tibetan examples among Gong's comparisons all begin with velars or uvulars one can combine Sagart and Gong's observations. If ' $\mathrm{K}$ ' is used to represent a velar or uvular, it becomes possible to more precisely state Laufer's Law as the merger of Tibeto-Burman ${ }^{*} \mathrm{~K}{ }^{w}$ ə and ${ }^{*} \mathrm{~K}{ }^{w a}$ as Tibetan Ko. ${ }^{19}$

\section{I5 Synchronic mysteries}

The rules of Shafer, von Koerber, Walleser, and de Jong sharpen the phonemic interpretation of the Tibetan script. This improved analysis aids in the discovery and the elegant statement of diachronic sound changes. Consequently, in tandem with the restatement of the exceptions to the sound laws presented here, a consideration of remaining problems in the phonetic interpretation of Old Tibetan is in order. The clarification of these issues may in future engender the discovery of, or more elegant statement of other sound laws.

Two issues remain unresolved in the interpretation of the Tibetan script. Old Tibetan has two graphic forms of the vowel which is called gi-gu in Written Tibetan. One of these characters is the same as the Written Tibetan $g i-g u \wedge<i>$. The other is the mirror image $\mathrm{s}<\mathrm{i}>$, and has thus come to be called the gi-gu inversé. Whether this character represents a phonetic reality or not remains controversial. Laufer (I9r4: p. 84) believes that these two graphs represent vowels which originally were phonemically contrasting in Old Tibetan,

\footnotetext{
${ }^{18}$ See note 16.

${ }^{19}$ The Tibetan pair ho-dom 'fox tail pendant' and hwa 'fox' still requires explanation.
} 
but which quickly began to collapse into one phoneme. Miller (1966, I993: pp. I56-I72) argues that the two represent sub-phonemic allophones of $/ \mathrm{i} /$. Other authors (e.g. Ulving I972 and Róna-Tas 1992: pp. 698-699) have regarded these two characters as meaningless graphic variants. This issue appears to have not received attention since 1993 and remains unresolved.

Old Tibetan sporadically but non-randomly has $a-h$ where this consonant is missing in later forms of Tibetan. Previous researchers have not attended to this question and taken for granted that syllables ending in $-h$ can be treated as open syllables. I see no reason to think a final $-h$ is any more meaningless than a final $-b$ or $-g$ (Hill 2005: pp. I $5-$ I 8 ), especially when it is kept in mind that those cases where $-h$ was not lost in Written Tibetan have regular reflexes distinct from open syllables in some Tibetan dialects (Hill 2009a: pp. $\left.{ }_{129-} \mathrm{I}_{3} \mathrm{I}\right)^{20}$ and that Chinese sometimes has a final $-\mathrm{k}$ corresponding to Tibetan final $-h$.

\begin{tabular}{|c|c|c|c|}
\hline Chinese & meaning & Tibetan & meaning \\
\hline 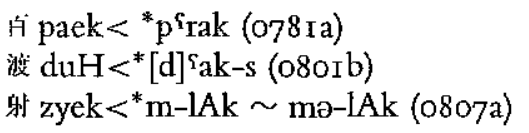 & $\begin{array}{l}\text { hundred } \\
\text { to ford } \\
\text { hit } w / \text { bow and arrow }\end{array}$ & $\begin{array}{l}\text { brgyah } \\
\text { hadah } \\
\text { mdah }\end{array}$ & $\begin{array}{l}\text { hundred } \\
\text { to pass } \\
\text { arrow }\end{array}$ \\
\hline
\end{tabular}

The final consonant $-h$ is potentially of great consequence in Tibeto-Burman historical phonology, and deserves more attention than it has received.

\section{I6 Diachronic mysteries}

Today's exceptions to sound laws are tomorrow's sound laws. Tibeto-Burman historical linguists following in the tradition of Benedict (I992) and Matisoff (2003) have been over eager to credit exceptions to 'allofamic' variation in the proto-language. ${ }^{21}$ Although such proto-variation probably does exist as examples such as 'have' (<Indo-European *kap, cf. Latin capio) and 'give' (<Indo-European *gebh, cf. Latin habeo) demonstrate, being satisfied with proto-variation as an explanation of anomalies is to abandon potential progress in the understanding of historical phonology and morphology.

The most valuable contribution of a survey of Tibetan sound laws is to draw new focus on the exceptions to these sound laws. After having surveyed what is known so far about Old Tibetan historical phonology those areas in need of better study merit focus. Exceptions to the respective sound laws presented have been provided above, but it is convenient to assemble them together here. The exceptions to Simon's Law are smra 'say', nur-smrig 'saffron', smre 'suffering', smreg 'root, remainder', smran', smren '(ritually) say'. As exceptions to either Sun's Law or Li's first Law are the words hdug 'stay', hdod 'desire' and hdom-pa 'fathom' which have connections to words with lateral initials but cannot be reconstructed as Li's *hl or Sun's *ml.

\footnotetext{
(2009a).

${ }^{20}$ This phenomenon is also described by Jin (1958: 12, e.g. $m d a h$ [da: $\left.{ }^{3}\right]$ 'arrow'), a work I overlooked in Hill

${ }^{21}$ Miller (1974) discusses the failings of this approach in his review of Benedict (1972). Similar problems persist in Matisoff (2003) as pointed out by Laurent Sagart (2006) in the case of Chinese and the present writer (Hill 2009b) in the case of Tibetan.
} 


\section{References}

U Ba Shin (1962). The Lokahteikpan. Rangoon: The Burma Historical Commission.

Baxter, William H. (I992). A Handbook of Old Chinese Phonology. Berlin: Mouton de Gruyter.

Benedict, Paul (1939). "Semantic Differentiation in Indo-Chinese." Harvard Journal of Asiatic Studies

4.3-4: pp. 21 3-229.

Benedict, Paul K. (1972). Sino-Tibetan: A Conspectus. Cambridge, Cambridge University Press.

Beyer, Stephen (1992). The Classical Tibetan Language. Albany: State University of New York Press; reprinted Delhi, Sri Satguru Publications, 1993.

Bodman, Nicolas C. (I980). "Proto - Chinese and Sino - Tibet Data towards establishing the nature of the relationship." Contributions to Historical Linguistics: Issues and Methods. Frans van Coetsem and Linda Waugh, (eds.). Leiden: Brill. pp. 34-199.

Bray, John (2008). "Missionaries, officials and the making of the 1826 Dictionary of the Bhotanta, or Boutan Language." Zentralasiatische Studien 37: pp. 33-75.

Chang, Betty Shefts (1971). "The Tibetan Causative phonology." Bulletin of the Institute of History and Philology 42: pp. 623-765.

Coblin, Weldon South (1974). "An early Tibetan word for horse." Joumal of the American Oriental Society 94: pp. I24-125.

Coblin, Weldon South (I976). "Notes on Tibetan Verbal Morphology." T"oung Pao 52: pp. 45-70.

Dempsey, Jakob (200I). "Remarks on the vowel system of old Burmese." Linguistics of the Tibeto-Burman Area 24.2: pp. 205-234. Errata 26.1 I 83.

Eimer, Helmut (1987). "Eine alttibetische Perfektbildung." Indo-Iranian Journal 30: pp. 21 3-214.

Foucaux, Philippe Édouard (I 858). Grammaire de la langue tibétaine. Paris: L'imprimerie impériale.

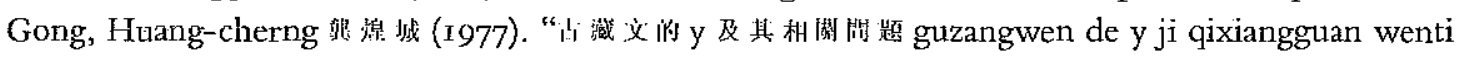
[Ancient Tibetan y and related questions]." Bulletin of the Institute of History and Philology, Academia

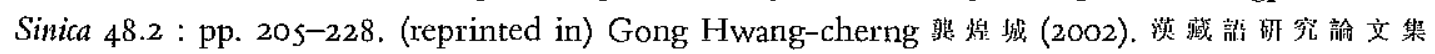

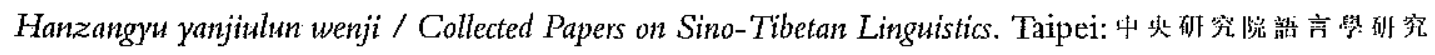

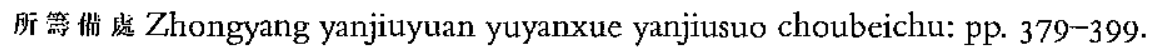

Gong, Hwang-cherng (1980). "A Comparative Study of the Chinese, Tibetan, and Burmese Vowel

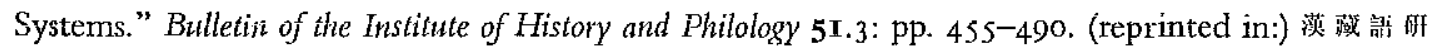
究諭文集 Hanzangyu yanjiulun wenji / Collected Papers on Sino-Tibetan Linguistics. Taipei: 出必研究院棓

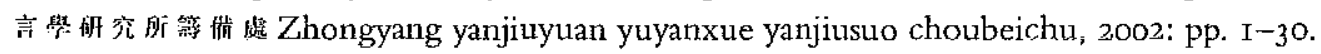

Gong, Hwang-cherng (I995). "The System of Finals in Proto-Sino-Tibetan". The Ancestry of the Chinese Language. William S. Y. Wang, (ed.) (Journal of Chinese linguistics. Monograph series 8) Berkeley: Project on Linguistic Analysis, University of California: pp. 4I-92. (reprinted in:)澡藏 部

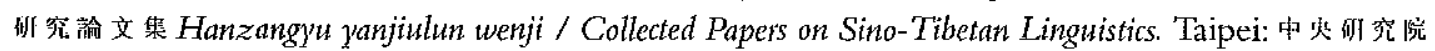

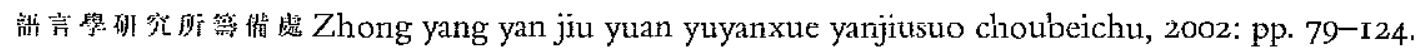

Hahn, Michael (1999). "Blags und Verwandtes (Miscellanea etymologica tibetica, VI)." Studia Tibetica et Mongolica (Festschrift Manfred Taube).(eds.) Helmut Eimer et al. (Indica et Tibetica 34). SwistallOdendorft: Indica et Tibetica Verlag. pp. I23-I25.

Hill, Nathan W. (2005). "Once more on the letter." Linguistics of the Tibeto-Burnan Area 28.2: pp. III-14I.

Hill, Nathan W. (2006). "Tibetan vwa 'fox' and the sound change Tibeto-Burman *wa -> Old Tibetan o." Linguistics of the Tibeto-Burman Area 29.2: pp. 75-90.

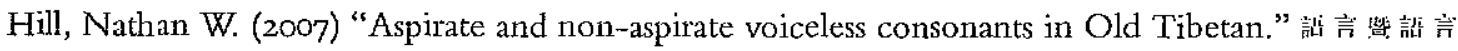
留 / Language and Linguistics 8.2: pp. 47I-493.

Hill, Nathan W. (2009a). "Tibetan $<$ h $->$ as a plain initial and its place in Old Tibetan Phonology." Linguistics of the Tibeto-Burman Area 32.I: pp. II 5-I 40. 
Hill, Nathan W. (2009b). "Review of Handbook of Proto-Tibeto-Burman: System and Philosophy of Sino-Tibetan Reconstruction. By James A. Matisoff. Berkeley: University of California Press,

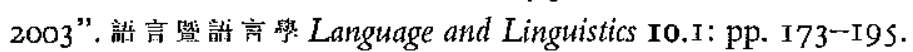

Hill, Nathan W. (2010). A Lexicon of Tibetan Verb Stems as Reported by the Grammatical Tradition. Munich: Bayerische Akademie der Wissenschaften.

Hill, Nathan W. (forthcoming). "The difference between Tibetan $<$ gy $>$ and $<$ g.y $>$ and ramifications for Old Tibetan phonology." Medieval Tibeto-Burman Languages IV. Leiden: Brill.

Houghton, Bernard (I 898). "Outlines of Tibeto-Burman Linguistic Palæontology." Journal of the Royal Asiatic Society: pp. 23-55.

Jacques, Guillaume (200I). "Les préfixes nominaux d- /g- en tibétain classique." Quinzième journée de linguistique - Asie orientale, EHESS, Paris, 08-06-200I.

Jacques, Guillaume (2003). "Un cas de dissimilation labiale en chinois archaique: la racine 'couvrir, renverser' et son equivalent en Tibetain." Cahiers de Linguistique Asie Orientale 32.I: pp.123-1 30.

Jacques, Guillaume 问的籍 (2008). 祘絾梛研究 Jiarongyu yanjiu. [Study of the Rgyalrong Language]. 比族出版补: Minzu Chubanshe.

Jacques, Guillaume (2009). "Tibetan wa-zur and Laufer's law." Linguistics of the Tibeto-Burman Area 32.I: pp. I4I-I44.

Jacques, Guillaume and Chen, Zhen (2010). Une verison rgyalrong de l'épopée de Gesar. (Senri Ethnological Reports 93). Osaka: National Museum of Ethnology.

Jäschke, Heinrich August (I88I). Tibetan English Dictionary. London: Unger Brothers.

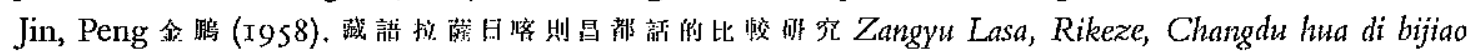
yanjiu. [Tibetan language, A comparative study of the Lha sa, Gźis ka rtse, and Chab mdo dialects.] Beijing: 科学出版祇. Kexue chubanshe.

de Jong, Jan Willem (1973). "Tibetan blag-pa and blags-pa." Bulletin of the School of Oriental and African Studies 36.2: pp. 309-312.

Judson, Adoniram (1893). Judson's Burmese-English dictionary. Rangoon: Printed by the superintendent, Government printing, Burma.

Karlgren, Bernhard (1964). Grammata Serica Recensa. Stockholm: Museum of Far Eastern Antiquities. von Koerber, H. N. (1935). Morphology of the Tibetan language. Los Angeles: Suttonhouse.

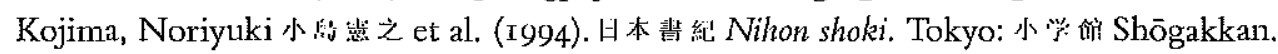

Kjellin, Olle (1975). “How to explain the 'tones' in Tibetan." アジアアフリカ語の䛸数研究 Ajia Afurika go no keisūkenkyū / Computational Analyses of Asian \& African Languages 2: pp. 37-52.

Laufer, Berthold (I 898/1899). "Ueber das va zur. Ein Beitrag zur Phonetik der tibetischen Sprache." Wiener Zeitschrift für die Kunde des Morgenlandes I2: pp. 289-307; 13: pp. 95-109, 199-226; reprinted in Kleinere Schriften von Berthold Laufer. (ed.) Hartmut Walravens. Wiesbaden: Franz Steiner Verlag, I976: pp. 6I-I22.

Laufer, Berthold (1914). "Bird divination among the Tibetans (notes on document Pelliot no 3530 , with a study of Tibetan phonology of the ninth century)." T'oung Pao 15: pp. I-I Io; reprinted in Hartmut Walravens \& Lokesh Chandra (eds.), Sino-Tibetan Studies, vol 2. New Delhi: Rakesh Goel. pp. $354-463$.

Li, Fang-Kuei (r933). "Certain Phonetic Influences of the Tibetan Prefixes upon the Root Initials." Bulletin of the Institute of History and Philology 6.2: pp. I35-I57.

Li, Fang-Kuei (I959). "Tibetan Glo-ba-'dring." Studia Sericn Bemhard Karlgren dedicate. Søren Egerod and Else Glahn (eds.) Copenhagen: Ejnar Munksgaard, pp. $55-\$ 9$.

Li Fang-Kuei (1976). "Sino-Tai". Computational Analysis of Asian and African Languages 3: pp. 39-48.

Luce, G. H. (1985). Phases of Pre-Pagán Burma: Languages and History. Oxford: Oxford University Press. Matisoff, James (2003). Handbook of Proto-Tibeto-Burman. Berkeley: University of California Press. 
Maung, Wun (I975). “Development of the Burmese language in the medieval period.”火顾外国棓火 "粉 Ōsaka gaikokugo daigaku gakuhō 36: pp. 63-1 I9.

Miller, Roy Andrew (I956). "Segmental diachronic phonology of a Ladakh (Tibetan) dialect." Zeitschrift der Deutschen Morganländischen Gesellschaft ro6: pp. 345-362.

Miller, Roy Andrew (I966). "Early evidence for vowel harmony in Tibetan." Language 42: pp. 252277.

Miller, Roy Andrew (I974). "Sino-Tibetan: Inspection of a Conspectus." Journal of the American Oriental Society 94.2: pp. I95-209.

Miller, Roy Andrew (1993). Prolegomena to the First Two Tibetan Grammatical Treatises. (Wiener Studien zur Tibetologie und Buddhismuskunde 30.) Vienna: Arbeitskreis für Tibetische und Buddhistische Studien Universität Wien.

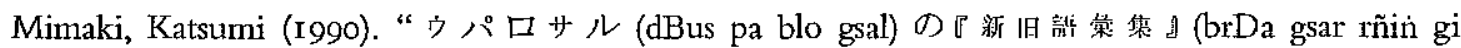
rnam par dbye ba) 校訂极初搞 Dbus pa blo gsal no 'Shin Kyuu Goi Shu'-Kōteibon Shokō / A Fourteenth-Century Tibetan Lexicographical Work, the brDa gsar rñin gi rnam par dbye ba by

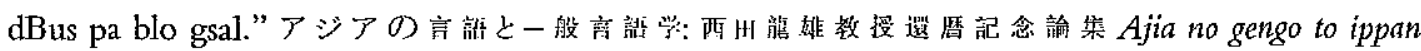
gengogaku: Nishida Tatsuo kyoju kanreki kinen ronshü / Asian Languages and General Linguistics, Festschrift for Prof. Tatsuo Nishida on the occasion of his 6oth birthday. Tokyo: 省

Mimaki, Katsumi (I992). "Index to two brda gsar rnying treatises: the works of dbus pa blo gsal and

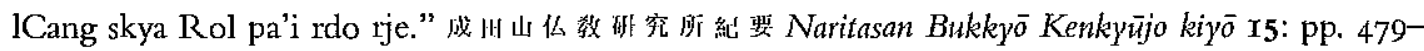
503.

Nishi, Yoshio (1999). Four Papers on Burmese: Toward the history of Burmese (the Myanmar language). Tokyo: Institute for the study of languages and cultures of Asia and Africa, Tokyo University of Foreign Studies.

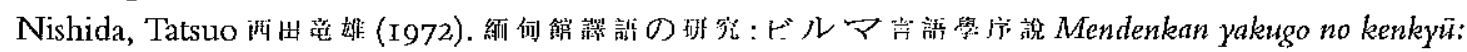
Biruma gengogaku josetsu / A Study of the Burmese-Chinese vocabulary, Mien-tien-kuan i-yu.

Norman, Jerry (1994) "Pharyngealization in Early Chinese." Journal of the American Oriental Society" II4.3: pp. 397-408.

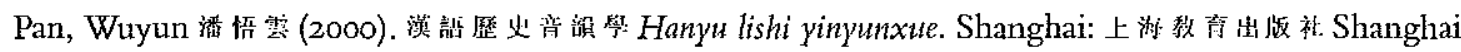
jiaoyu chubanshe.

Pulleyblank, Edwin G. (1962). "Consonantal system of Old Chinese. Part II." Asia Major (New Series) 9.2: pp. 206-265.

Pulleyblank, Edwin G. (I979). "The Chinese Cyclical Signs as Phonograms." Journal of the American Oriental Society 99. I: pp. 24-38.

Róna-Tas, András (I992). "Reconstructing Old Tibetan." Ihara Shoren and Yamaguchi Zuiho (eds.) Tibetan Studies: Proceedings of the sth Seminar of the International Association for Tibetan Studies, Narita 1989. Narita: Naritasan Shinshoji. Vol 2. pp. 697-704.

Sagart, Laurent (1988). "Nord et sud dans la langue et L'écriture des Shang". T'oung Pao 74.4-5: pp. 249-254.

Sagart, Laurent (I999). The Roots of Old Chinese. Amsterdam: John Benjamins Publishing Company.

Sagart, Laurent (2003). "The vocabulary of cereal cultivation and the phylogeny of East $\Lambda$ sian languages." Bulletin of the Indo-Pacific Prehistory Association 23.1: pp. I27-1 36.

Sagart, Laurent (2006). "Handbook of Proto-Tibeto-Buman: System and philosophy of Sino-Tibeto-Burman reconstruction. By James A Matisoff." Diachronica 23:r: pp. 206-223.

Sagart, Laurent and William H. Baxter (2009). "Reconstructing Old Chinese uvulars in the BaxterSagart system (Version 0.99)." Cahiers de Linguistique - Asie Orientale 38.2: pp. 22 I-244.

Schiefner, Anton (1852). "Tibetischen Studien." Mélanges asiatiques tirés du Bulletin de l'Académie impériale des sciences de St.-Pétersbong I: pp. 324-394. 
Schmidt, Isaak Jakob (1839). Grammatik der tibetischen Sprache. St. Petersburg: Kaiserlichen Akademie der Wissenschaften.

Schroeter, Frederic Christian Gotthelf (1826). A Dictionary of the Bhotanta or Boutan Language. Serampore.

Schuessler, Axel (2003). "What Are Cognates and What Are Variants in Chinese Word Families?"

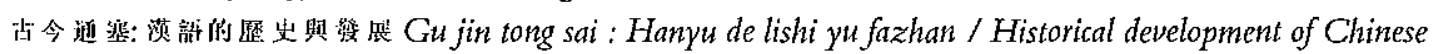

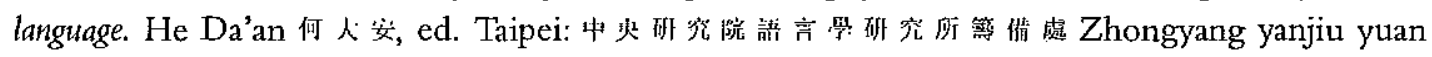
yuyanxue yanjiusuo choubeichu: pp. $225-248$.

Schuessler, Axel (2007). ABC Etymological Dictionary of Old Chinese. Honolulu: University of Hawai'i Press.

Shafer, Robert (I950/SI). "Studies in the morphology of the Bodic verbs." Bulletin of the School of Oriental and African Studies I3.3 and 4: pp. 702-724 and I017-1031.

Simon, Walter (1929). "Tibetisch-Chinesische Wortgleichungen, ein Versuch." Mitteilungen des Seminars für Orientalische Sprachen an der Friedrich Wilhelms-Universität zu Berlin 32: pp. I57-228.

Simon, Walter (1964). "Tibetan Lexicography and Etymological Research." Transactions of the Philological Socieiy 63.I: pp. 85-107.

Sprigg, Richard Keith (I972). "A Polysystemic Approach, in Proto-Tibetan Reconstruction, to Tone and Syllable-Initial Consonant Clusters." Bulletin of the School of Oriental and African Studies 35.3: pp. $546-587$.

Sun, Jackson T. S. (I993). 'A Historical-Comparative study of the Tani (Mirish) Branch in TibetoBurman', $\mathrm{PhD}$ dissertation, University of California at Berkeley.

Tauscher, Helmut (2008). Catalogue of the Gondhla Proto-Kanjur. Vienna: Arbeitskreis fuir Tibetische und Buddhistische Studien Universität Wien.

Ulving, Tor (1972). "Tibetan vowel harmony revisited." T'oung Pao 58: pp. 203-217.

Uray, Géza (1968). "A Chronological Problem in the Old Tibetan Chronicle." Acta orientalia Academiae Scientiarum Hungaricae II: pp. 268-269.

Walleser, Max (I926). Zur Aussprache des Sanskrit und Tibetischen. (Materialien zur Kunde des Buddhismus II). Heidelberg: O. Harrassowitz.

NATHAN W. HILL School of Oriental and African Studies, University of London 